\title{
Optimal Gestational Weight Gain Based on Different Body Mass Index and its Relation with Adverse Pregnancy Outcome in a Tertiary Care Hospital
}

\author{
Tehmina Parveen*, Zakia Sheikh, Saira Jam, Asif Zia Akhtar, Anjum Ara Hassan, Sana Ghayas \\ Department of Obstetrics and Gynaecology, Hamdard University Hospital, Karachi, Pakistan.
}

\begin{abstract}
Introduction: Maternal and neonatal complications have been linked to pre-pregnancy Body Mass Index (BMI) and gestational weight gain. Controlling of BMI and weight gain during pregnancy is desirable in order to optimize the maternal and perinatal outcomes. The aim of this study is to determine gestational weight gain in different BMI groups and its relation with pregnancy outcomes.
\end{abstract}

Methods: This observational study was performed on 370 reproductive age women with singleton pregnancy from January 2015 to December 2016 at Hamdard University Hospital, Karachi. BMI and total GWG were calculated and patients were followed to see pregnancy outcomes. Data was analysed by using SPSS 21.

Results: Out of 370 participants, $8(2.2 \%)$ were underweight, $119(32.2 \%)$ were healthy, $126(34.1 \%)$ were overweight and $86(23.2 \%)$ were obese and 31(8.4\%) were very obese.

Overweight and obese multiparous women gained weight more than IOM recommendations. Adverse pregnancy outcomes like GDM 124(33.5\%), PIH 69(18.6\%), Pre-eclampsia 9(2.4\%), placental abruption 14(3.8\%), cesarean section 214(57.8\%), postoperative wound infection 54(14.6\%), macrosomia 27(7.3\%), low Apgar score 112(30.3\%) and NICU admissions 174(47\%) were noted in overweight and obese women with excessive GWG. We interestingly, noted adverse pregnancy outcomes in women with upper limit of normal BMI and GWG ranges.

Conclusion: Implementing optimal BMI and GWG helps to avoid adverse pregnancy outcomes. Asians especially Pakistani women need local BMI and GWG recommendations to have better pregnancy outcomes.

Keywords: Body mass index (BMI), Gestational weight gain (GWG), Gestational diabetes mellitus (GDM), Pregnancy induced hypertension (PIH), Cesarean section, Low birth weight, NICU admission.

\section{INTRODUCTION}

Gestational weight gain (GWG) is one of the important determinants of pregnancy outcome [1]. Maternal and neonatal complications have been linked to pre-pregnancy body mass index (BMI) and gestational weight gain [2]. Pregnancy weight gain is substantially influenced by several factors including maternal, physiological and social characteristics [3]. The rate of weight gain is also variable throughout pregnancy and its timing during pregnancy has an impact on birth weight. Controlling of BMI and weight gain during pregnancy is desirable in order to optimize the perinatal outcomes. It is not always possible for all women to be at an ideal BMI at the time of conception. Weight gain during pregnancy, on the other hand, is more manageable by dietary counseling and lifestyle modification [4]. Several studies have ascertained the positive association between lower pregnancy weight gain and the risk of low birth weight and pre-term delivery [1-5]. Increased weight gain on the other hand results in higher chances of large for dates, gestational hypertension and need for augmentation of labor

*Address correspondence to this author at the Department of Obstetrics and Gynaecology, Hamdard University Hospital, Karachi, Pakistan.

E-mail: tehmina.jawwad@yahoo.com
[1]. Increase weight gain is also found to be associated with overweight and obesity in early childhood [6].

WHO in 2004 [7] and Institute of medicine (IOM) revised the pregnancy weight gain guidelines in 2009 by including four categories of BMI in $\mathrm{kg} / \mathrm{m} 2$ categories such as underweight $(<$ 18.5), normal (18.5 - 24.9), overweight (25 - 29.9) and obese (> 30) [8]. The recommended weight gain $(\mathrm{kg})$ for the four categories are; underweight (12.5 - $18 \mathrm{~kg})$, normal (11.5 - 16 $\mathrm{kg}$ ), overweight (7 - 11.5 kg), and obese (5 - $9 \mathrm{~kg})$ [5]. It is observed that in majority of pregnancies the weight gain is not within the range recommended by these guidelines (Table 1) [5]. It is either too little or too much, especially in the obese women the lower gains risk are smaller [6].

Table 1. The American Institute of Medicine (IOM) Recommendations for Gestational Weight Gain.

\begin{tabular}{|l|c|c|}
\hline $\begin{array}{c}\text { Pre-pregnant BMI } \\
\text { Categories }\end{array}$ & BMI & $\begin{array}{c}\text { According to IOM } \\
\text { Recommendations }\end{array}$ \\
\hline Underweight & $<18.5$ & $12.5-18 \mathrm{~kg}$ \\
\hline Healthy & $18.5-24.9$ & $11.5-16 \mathrm{~kg}$ \\
\hline Overweight & $25-29.9$ & $7-11.5 \mathrm{~kg}$ \\
\hline Obese & 30.0 & $5-9 \mathrm{~kg}$ \\
\hline
\end{tabular}

www.njhsciences.com 
In a study it was found that there is association of adverse pregnancy outcome with pre-pregnancy BMI and gestation weight gain. Both the overweight $(5.1 \%$ vs. $3.4 \%, \mathrm{p}=0.012)$ and obese women $(7.4 \%$ vs. $3.4 \%, \mathrm{p}<0.001)$ were likely to deliver LGA babies compared to normal BMI women. Obese women were significantly more likely to undergo caesarean section as compared to women with normal BMI $(27.8 \%$ vs. $23.6 \%, \mathrm{p}=0.011$ ) [9].

A large meta-analysis showed significant association between maternal obesity and adverse pregnancy outcomes, it is related with increased healthcare costs, clinical technical difficulties and lifelong consequences for the mother and her baby [10].

Limited literature is available on the pattern of pregnancy weight gain of women from developing countries and due to retrospective study designs of studies $[9,11]$, therefore, we conduct this study to determine gestational weight gain in different BMI groups and its relation with pregnancy outcomes. This study will help to implement WHO and IOM recommendations to our own population.

\section{OBJECTIVE}

(1) To determine the optimal gestation weight during pregnancy with respect to BMI.

(2) To determine relation between optimal weight gain and pregnancy outcome.

\section{MATERIALS AND METHODS}

This prospective observational study conducted in department of Obstetrics and Gynaecology, Hamdard University Hospital, Taj Medical Complex Karachi from January 2015 to December 2016. Total 370 reproductive age women (15 - 40 years) with singleton pregnancy were included and women with multiple pregnancy and pre-existing medical disorders (like DM, HTN and liver disorders) were excluded from this study.

\section{DATA COLLECTION PROCEDURE}

Women with inclusion criteria were enrolled in the study after taking their informed consent. Pre-pregnancy weight was obtained by self- reported or weight at first antenatal visit (before 18 weeks). Height was measured in antenatal clinic. BMI was calculated $\left(\mathrm{kg} / \mathrm{m}^{2}\right)$ and categorized according to WHO criteria. Total weight gain was calculated using the weight at the time of delivery.

Patients were followed to record pregnancy outcomes like GDM, PIH, Pre-Eclampsia, placental abruption, preterm labor or miscarriage, an aesthesia and postoperative complications, Mode of delivery, fetal weight, Apgar score and neonatal NICU admission.

\section{DATA ANALYSIS}

The data was entered and analyzed using SPSS version 21.0. Frequency and percentage were computed for categorical variable like BMI categories, preterm delivery, large for gestational age, low birth weight and cesarean delivery. Mean and standard deviations was computed for continuous variables like age, gestational age, body mass index, gestational weight gain, weight of baby.

Effect modifiers like age, gestational weight gain and BMI was controlled through stratification by applying chi squared test and $p$-value $<0.05$ was considered significant.

\section{RESULTS}

Total 370 women fulfilling inclusion criteria were included in this study, majority of patients were in the age group from 26-30 years $122(33 \%)$ and multipara $238(64.3 \%)$ with previous normal vaginal deliveries (Figs. 1, 2).

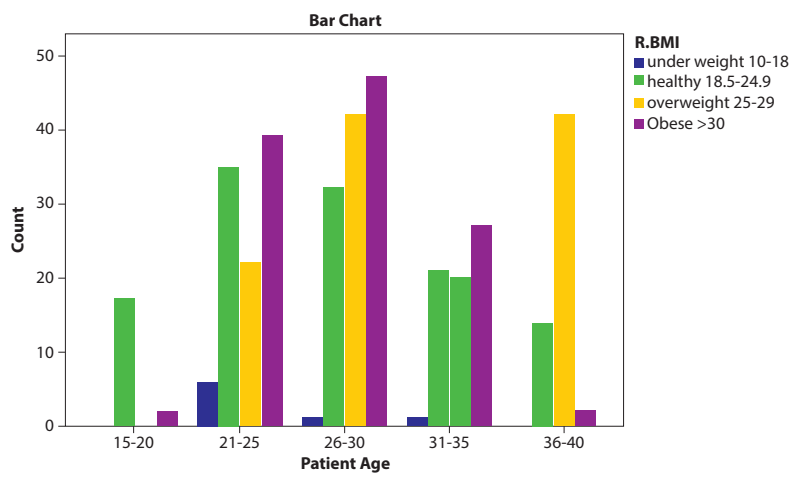

Fig. (1). Distribution of Women According to Age According to in Different BMI Categories.

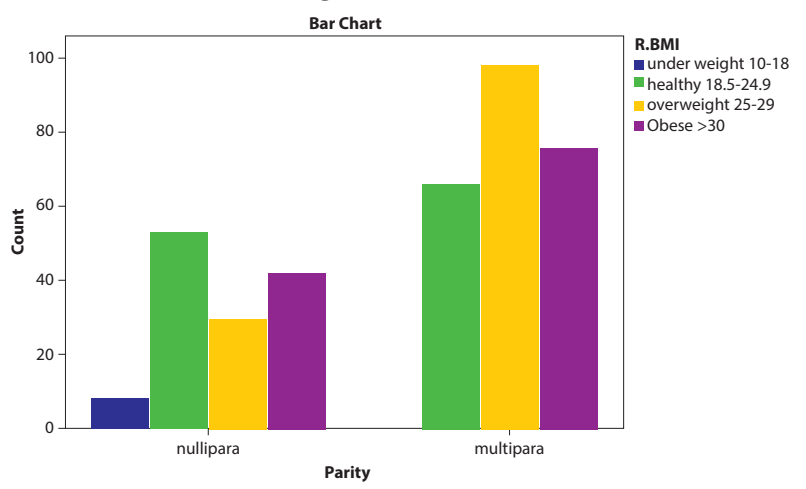

Fig. (2). Distribution of Women Parity in Different BMI Categories.

Out of 370 participants, $8(2.2 \%)$ were underweight, $119(32.2 \%)$ were healthy, $126(34.1 \%)$ were overweight and $86(23.2 \%)$ were obese and $31(8.4 \%)$ were very obese.

The underweight women had gestational weight gain fulfilling IOM recommendations, comparatively, 5(4.2\%) women with healthy BMI gained $>16 \mathrm{~kg}$. 36(28.6\%) and $8(6.3 \%)$ women of overweight category had gained $11-15 \mathrm{~kg}$ 
and $16-20 \mathrm{~kg}$ respectively. Similarly, 27(23.1\%) and 4(3.4\%) obese women showed excessive GWG i.e. $11-15 \mathrm{~kg}$ and $16-20 \mathrm{~kg}$ respectively according to IOM recommendations (Table 2).

Our study showed that multiparous women of age $>30$ years had greater BMI as compared to nulliparous young women and gained more weight (Figs. 1, 2).

Poor maternal and fetal outcomes were seen in women with greater BMI, who had excessive GWG (Table 3).

Table 2. Weight Gain in Different BMI Categories.

\begin{tabular}{|c|c|c|c|c|c|c|}
\hline \multirow[t]{2}{*}{ BMI } & \multirow{2}{*}{$\begin{array}{l}\text { IOM } \\
\text { Recommendation } \\
\text { For Best Weight } \\
\text { Gain }\end{array}$} & \multicolumn{4}{|c|}{ Weight Gain } & \multirow{2}{*}{$\begin{array}{l}P \text {-value } \\
\text { chi-square } \\
\text { test }\end{array}$} \\
\hline & & $1-5 \mathrm{~kg}$ & $6-10 \mathrm{~kg}$ & $11-15 \mathrm{~kg}$ & $16-20 \mathrm{~kg}$ & \\
\hline \multirow{2}{*}{$\begin{array}{l}\text { Underweight } \\
10-188 \\
(2.2 \%)\end{array}$} & \multirow{2}{*}{$12.5-18 \mathrm{~kg}$} & 0 & 0 & 8 & 0 & \multirow{8}{*}{0} \\
\hline & & $0.0 \%$ & $0.0 \%$ & $100.0 \%$ & $0.0 \%$ & \\
\hline \multirow{2}{*}{$\begin{array}{l}\text { Healthy } \\
18.5-24.9119 \\
(32.2 \%)\end{array}$} & \multirow{2}{*}{$11.5-16 \mathrm{~kg}$} & 21 & 48 & 45 & 5 & \\
\hline & & $17.6 \%$ & $40.3 \%$ & $37.8 \%$ & $4.2 \%$ & \\
\hline \multirow{2}{*}{$\begin{array}{l}\text { Overweight } \\
25-29126 \\
(34.1 \%)\end{array}$} & \multirow{2}{*}{$7-11.5 \mathrm{~kg}$} & 12 & 70 & 36 & 8 & \\
\hline & & $9.5 \%$ & $55.6 \%$ & $28.6 \%$ & $6.3 \%$ & \\
\hline \multirow{2}{*}{$\begin{array}{l}\text { Obese }>30 \\
117(31.6 \%)\end{array}$} & \multirow{2}{*}{$5-9 \mathrm{~kg}$} & 23 & 63 & 27 & 4 & \\
\hline & & $19.7 \%$ & $53.8 \%$ & $23.1 \%$ & $3.4 \%$ & \\
\hline
\end{tabular}

Table 3. Maternal Out Comes in Different BMI and Weight Gain Categories.

\begin{tabular}{|c|c|c|c|c|c|c|}
\hline $\begin{array}{c}\text { Outcome } \\
\text { Total }\end{array}$ & $\begin{array}{l}\text { BMI* } \\
\text { Weight } \\
\text { Gain** }\end{array}$ & $\begin{array}{c}\text { Underweight } \\
1-5 \mathrm{~kg}\end{array}$ & $\begin{array}{l}\text { Healthy } \\
6-10 \text { kg }\end{array}$ & $\begin{array}{l}\text { Underweight } \\
11-15 \mathrm{~kg}\end{array}$ & $\begin{array}{c}\text { Obese } \\
16-20 \mathrm{~kg}\end{array}$ & p-value \\
\hline GDM & $124(33.5 \%)$ & $\begin{array}{c}1(.8) \\
8(6.5)\end{array}$ & $\begin{array}{c}7(5.6) \\
54(43.5)\end{array}$ & $\begin{array}{l}53(42.7) \\
48(38.7)\end{array}$ & $\begin{array}{c}63(50.8)^{*} \\
14(11.3)^{* *}\end{array}$ & 0.000 \\
\hline $\mathrm{PIH}$ & $69(18.6 \%)$ & $\begin{array}{c}0(0) \\
4(5.8)\end{array}$ & $\begin{array}{l}10(14.5) \\
22(31.9)\end{array}$ & $\begin{array}{c}23(33.3) \\
29(42)\end{array}$ & $\begin{array}{c}36(52.2)^{*} \\
14(20.3)^{* *}\end{array}$ & 0.000 \\
\hline Pre-eclampsia & $9(2.4 \%)$ & $\begin{array}{c}0(0) \\
1(11.1)\end{array}$ & $\begin{array}{c}1(11.1) \\
0(0)\end{array}$ & $\begin{array}{l}1(11.1) \\
4(44.4)\end{array}$ & $\begin{array}{c}7(77.8)^{*} \\
4(44.4)^{* *}\end{array}$ & $\begin{array}{l}0.037 \\
0.000\end{array}$ \\
\hline Abruption & $14(3.8 \%)$ & $\begin{array}{c}0(0) \\
1(7.1)\end{array}$ & $\begin{array}{c}2(14.3) \\
7(50)\end{array}$ & $\begin{array}{c}11(78.6) \\
6(42.9)\end{array}$ & $\begin{array}{l}1(7.1)^{*} \\
0(0)^{* *}\end{array}$ & $\begin{array}{l}0.005 \\
0.453\end{array}$ \\
\hline Pretarm Labour & $70(18.9 \%)$ & $\begin{array}{l}1(1.4) \\
3(4.3)\end{array}$ & $\begin{array}{l}25(35.7) \\
48(68.6)\end{array}$ & $\begin{array}{l}24(34.3) \\
11(15.7)\end{array}$ & $\begin{array}{l}20(28.6)^{*} \\
8(11.4)^{* *}\end{array}$ & $\begin{array}{l}0.847 \\
0.000\end{array}$ \\
\hline Miscarriages & $10(2.7 \%)$ & $\begin{array}{l}0(0) \\
0(0)\end{array}$ & $\begin{array}{l}0(0) \\
0(0)\end{array}$ & $\begin{array}{c}10(100) \\
3(30)\end{array}$ & $\begin{array}{c}0(0)^{*} \\
7(70)^{* *}\end{array}$ & 0.000 \\
\hline Fetal Distress & $65(17.6 \%)$ & $\begin{array}{l}1(1.5) \\
8(12.3)\end{array}$ & $\begin{array}{l}22(33.8) \\
20(30)\end{array}$ & $\begin{array}{l}33(50.8) \\
24(36.9)\end{array}$ & $\begin{array}{l}9(13.8)^{*} \\
13(20)^{* *}\end{array}$ & $\begin{array}{l}0.002 \\
0.000\end{array}$ \\
\hline $\begin{array}{l}\text { Shoulder } \\
\text { Dystocia }\end{array}$ & $17(4.6 \%)$ & $\begin{array}{l}0(0) \\
0(0)\end{array}$ & $\begin{array}{l}0(0) \\
0(0)\end{array}$ & $\begin{array}{l}9(52.9) \\
17(100)\end{array}$ & $\begin{array}{c}8(47.1)^{*} \\
0(0)^{* * *}\end{array}$ & $\begin{array}{l}0.025 \\
0.000\end{array}$ \\
\hline $\begin{array}{l}\text { Anesthesia } \\
\text { Complications }\end{array}$ & $10(2.7)$ & $\begin{array}{c}0(0) \\
6(60)\end{array}$ & $\begin{array}{l}2(20 .) \\
2(20)\end{array}$ & $\begin{array}{l}5(50) \\
1(10)\end{array}$ & $\begin{array}{l}3(30)^{*} \\
1(10)^{* *}\end{array}$ & $\begin{array}{l}0.645 \\
0.005\end{array}$ \\
\hline POW infection & $54(14.6 \%)$ & $\begin{array}{c}0(0 \\
2(3.7)\end{array}$ & $\begin{array}{c}5(9.3) \\
15(27.8)\end{array}$ & $\begin{array}{l}23(42.6) \\
22(40.7)\end{array}$ & $\begin{array}{l}26(48.1)^{*} \\
15(27.8)^{* *}\end{array}$ & $\begin{array}{l}0.000 \\
0.000\end{array}$ \\
\hline
\end{tabular}


Out of 370, one hundred and twenty four (33.5\%) women developed GDM, of these 53(42.7\%) were overweight and $63(50.8 \%)$ were obese. $48(38.7 \%)$ gained $11-15 \mathrm{~kg}$ weight and 14(11.3\%) gained 16-20kg. Similarly, 69(18.6\%) women developed PIH and majority i.e. 23(33.3\%) and 36(52.2\%) were overweight and obese respectively and had excessive GWG. $9(2.4 \%)$ pregnancies complicated with pre-eclampsia, majority $7(77.8 \%)$ were obese and gained more than $11 \mathrm{~kg}$. $14(3.8 \%)$ women developed placental abruption, of these $11(78.6 \%)$ were overweight and $1(7.1 \%)$ were obese who gained $>11 \mathrm{~kg}$.

$70(18.9 \%)$ women had pre-term delivery, but no significant association was found with obesity. 10(2.7\%) women miscarried their fetus, majority of them were obese and had excessive GWG. Similarly, 65(17.6\%) had fetal distress, and majority were overweight and obese and had excessive GWG $33(50.8 \%)$ in overweight $9(13.8 \%)$ in obese, $17(4.6 \%)$ women had shoulder dystocia $9(52.9 \%)$ overweight, $8(47.1 \%)$ obese who gained excessive weight. 10(2.7\%) women developed spinal headache, 5(50\%) were overweight and $3(30 \%)$ were obese women.54(14.6\%) had postoperative wound infection $23(42.6 \%)$ were overweight $26(48.1 \%)$ were obese with excessive GWG.

Surgical intervention like instrumental deliveries and caesarean sections were more commonly seen in obese women with excessive GWG (Table 4). 214(57.8\%) women had caesarean section, out of them $97(45.3 \%)$ were obese. but no significant difference was found in overweight and healthy BMI groups i.e. 58(27.1\%). Moreover, 24(6.5\%) women had instrumental deliveries, out of them 13(54.2\%) women were obese and 9(37.5\%) were overweight with excessive GWG (Table 4).

Our study showed strong association of greater BMI and excessive GWG with Poor Apgar scores, Nicu admissions and abnormal birth weight (Table 5).

Table 4. Mode of Delivery in Different BMI and Weight Gain Categories.

\begin{tabular}{|c|c|c|c|c|c|c|}
\hline$\underset{\text { Total }}{\text { Outcome }}$ & $\begin{array}{c}\text { BMI* } \\
\text { Weight Gain** }\end{array}$ & $\begin{array}{c}\text { Underweight } \\
1-5 \mathrm{~kg}\end{array}$ & $\begin{array}{l}\text { Healthy } \\
\text { 6-10 kg }\end{array}$ & $\begin{array}{c}\text { Underweight } \\
11-15 \mathrm{~kg}\end{array}$ & $\begin{array}{l}\text { Obese } \\
16-20 \text { kg }\end{array}$ & p-value \\
\hline $\begin{array}{l}\text { SVD } \\
\text { Instrumental }\end{array}$ & $125(33.8 \%)$ & $\begin{array}{l}7(5.6) \\
20(16\end{array}$ & $\begin{array}{l}52(41.6) \\
68(54.4)\end{array}$ & $\begin{array}{l}59(47.2) \\
35(28)\end{array}$ & $\begin{array}{c}7(5.6)^{*} \\
2(1.6)^{* *}\end{array}$ & $\begin{array}{l}.000 \\
.132\end{array}$ \\
\hline Delivery & $24(6.5 \%)$ & $\begin{array}{l}0(0.0) \\
0(0 \%)\end{array}$ & $\begin{array}{l}2(8.3) \\
6(25)\end{array}$ & $\begin{array}{l}9(37.5) \\
18(75)\end{array}$ & $\begin{array}{c}13(54.2)^{*} \\
0(0)^{* *}\end{array}$ & $\begin{array}{l}.026 \\
.000\end{array}$ \\
\hline $\begin{array}{l}\text { Caesarean } \\
\text { Section }\end{array}$ & $214(57.8 \%)$ & $\begin{array}{c}1(.5) \\
35(16.4)\end{array}$ & $\begin{array}{l}58(27.1) \\
107(50)\end{array}$ & $\begin{array}{l}58(27.1) \\
57(26.6)\end{array}$ & $\begin{array}{c}97(45.3)^{*} \\
15(7)^{* *}\end{array}$ & $\begin{array}{l}.000 \\
.001\end{array}$ \\
\hline
\end{tabular}

Table 5. Fetal Out Comes in Different BMI and Weight Gain Categories.

\begin{tabular}{|c|c|c|c|c|c|c|}
\hline $\begin{array}{l}\text { Fetal } \\
\text { Weight }\end{array}$ & $\begin{array}{c}\text { BMI* } \\
\text { Weight Gain** }\end{array}$ & $\begin{array}{c}\text { Underweight } \\
1-5 \mathrm{~kg}\end{array}$ & $\begin{array}{l}\text { Healthy } \\
6-10 \mathrm{~kg}\end{array}$ & $\begin{array}{c}\text { Underweight } \\
11-15 \mathrm{~kg}\end{array}$ & $\begin{array}{l}\text { Obese } \\
16-20 \mathrm{~kg}\end{array}$ & p-value \\
\hline $\begin{array}{l}\text { Normal Birth Weight } \\
2.5-3.5 \mathrm{~kg}\end{array}$ & $\begin{array}{c}252 \\
(68.1 \%)\end{array}$ & $\begin{array}{l}7(2.8) \% \\
42(16.7)\end{array}$ & $\begin{array}{l}88(34.9) \\
110(43.7)\end{array}$ & $\begin{array}{l}86(34.1) \\
91(36.1)\end{array}$ & $\begin{array}{l}71(28.2)^{*} \\
9(3.6)^{* *}\end{array}$ & \multirow[t]{4}{*}{$\begin{array}{l}0.001 \\
0.000\end{array}$} \\
\hline $\begin{array}{l}\text { Low Birth Weight } \\
2-2.5 \mathrm{~kg}\end{array}$ & $\begin{array}{c}87 \\
(23.5 \%)\end{array}$ & $\begin{array}{c}0(0) \\
13(14.9)\end{array}$ & $\begin{array}{c}27(31) \\
59(67.8)\end{array}$ & $\begin{aligned} & 23(26.4) \\
& 7(8.0)\end{aligned}$ & $\begin{array}{l}37(42.5)^{*} \\
8(9.2)^{* *}\end{array}$ & \\
\hline $\begin{array}{l}\text { Very Low } \\
\text { Birth }<2.0 \mathrm{~kg}\end{array}$ & $\begin{array}{c}4 \\
(1.1 \%)\end{array}$ & $\begin{array}{l}1(25) \\
0(0)\end{array}$ & $\begin{array}{l}2(50) \\
1(25)\end{array}$ & $\begin{array}{l}1(25) \\
3(75)\end{array}$ & $\begin{array}{l}0(0)^{*} \\
0(0)^{* *}\end{array}$ & \\
\hline $\begin{array}{l}\text { Good Size/ } \\
\text { Macrocosmic Baby } \\
3.5-4.5 \mathrm{~kg}\end{array}$ & $\begin{array}{c}27 \\
(7.3 \%)\end{array}$ & $\begin{array}{c}0(0) \\
1(3.7)\end{array}$ & $\begin{array}{c}2(7.4) \\
11(40.7)\end{array}$ & $\begin{array}{l}16(59.3) \\
15(55.6)\end{array}$ & $\begin{array}{l}9(33.3)^{*} \\
0(0)^{* *}\end{array}$ & \\
\hline NICU Admissn & $\begin{array}{c}174 \\
(47 \%)\end{array}$ & $\begin{array}{c}2(1.1) \\
20(11.5)\end{array}$ & $\begin{array}{l}39(22.4) \\
85(48.9)\end{array}$ & $\begin{array}{l}61(35.1) \\
54(31)\end{array}$ & $\begin{array}{l}72(41.4)^{*} \\
15(8.6)^{* *}\end{array}$ & $\begin{array}{l}0.000 \\
0.002\end{array}$ \\
\hline \multicolumn{7}{|l|}{ APGAR Score } \\
\hline Good & $\begin{array}{c}257 \\
(69.5 \%)\end{array}$ & $\begin{array}{c}6(2.3) \\
42(16.3)\end{array}$ & $\begin{array}{l}86(33.5) \\
117(45.5)\end{array}$ & $\begin{array}{c}77(30) \\
94(36.6)\end{array}$ & $\begin{array}{l}88(34.2)^{*} \\
4(1.6)^{* *}\end{array}$ & \multirow{2}{*}{$\begin{array}{l}0.178 \\
0.000\end{array}$} \\
\hline Low & $\begin{array}{c}112 \\
(30.3 \%)\end{array}$ & $\begin{array}{c}6(2.3) \\
42(16.3)\end{array}$ & $\begin{array}{c}86(33.5) \\
117(45.5)\end{array}$ & $\begin{array}{c}77(30) \\
94(36.6)\end{array}$ & $\begin{array}{c}88(34.2)^{*} \\
4(1.6)^{* \wedge}\end{array}$ & \\
\hline
\end{tabular}

*association with BMI categories.

**association with Gestational weight gain. 
112(30.3\%) babies were born with poor Apgar score, majority were delivered by overweight and obese women 49(43.8\%) and $29(25.9 \%)$ respectively. $174(47 \%)$ babies admitted in nursery, $61(35.1 \%)$ of overweight and $72(41.4 \%)$ of obese women. Macrosomia 27(7.3\%) were more commonly found in obese and overweight women 9(33.3\%) and 16(59.3\%) respectively, while no significant difference noted in terms of LBW and normal weight babies. Moreover, we found increase rate of pregnancy related complications in women who had GWG at upper limit of normal according to IOM's recommendations.

\section{DISCUSSION}

Obesity is a major obstetric challenge in recent years globally, it showed linear association with poor maternal and fetal outcomes. We found strong relation of obesity with maternal and fetal complications. The incidence of morbid obesity in our reproductive age women was $8.4 \%, 34.1 \%$ women were overweight, $23.2 \%$ were obese and $2.2 \%$ women were underweight.

Similar levels were reported by Galan and Hernandez 8.3\% women were morbidly obese while $5.5 \%$ were underweight [12]. ACOG committee found extreme obesity in $8 \%$ of reproductive age women [13], Cynthia and linda [14] reported $23 \%$ while, lynch et al. [15] found $25 \%$ obese women in their population. On the other hand, a study from china showed $13.2 \%$ overweight, $3.6 \%$ obese and $15.8 \%$ underweight [16].

In our study, most of the multiparous older women with mean age $29 \pm 6$, had greater BMI and had excessive GWG. Multiple studies reported similar data [16-19].

According to our study, the proportion of women who gained optimal weight in their pregnancy (IOM recommendations) was $37.8 \%$ in healthy BMI category, $55.6 \%$ in overweight and $53.8 \%$ in obese category. 5(4.2\%) women had excessive GWG in healthy category, 44(34.9\%) in overweight and $31(26.5 \%)$ in obese category. A study from Thailand showed $60 \%$ weight gain according to IOM [11].

We found that excessive GWG was linked to adverse pregnancy outcomes like GDM, PIH, Pre-eclampsia, macrosomia, and postoperative wound infections. The overall incidence of severe pre-eclampsia was $9(2.4 \%)$ and macrosomia 27(7.3\%), Zhenyu Chen [16] and Peng shi [17] from China, Sunsaneevithakul P. from Thailand [11], Shama M. [9] and Ali SH. [20] from Pakistan 10 reported the similar results. O Brian et al. [18] reported 2-10\% hypertensive disorder including pre-eclampsia and this risk doubles with each $5-7 \mathrm{~kg} / \mathrm{m}^{2}$ increase in BMI.

On the other hand, In a more recent meta-analysis of 36 studies with nearly 1.7 million subjects, BMI was a weak predictor of pre eclampsia [19]. Moreover, Heller Stadt et al. found a statistically significant linear trend in increasing incidence of macrosomia with increasing GWG [21].

Maternal obesity is an important risk factor for the development of GDM particularly moderate to severe obesity, In our study 124(33.5\%) women developed GDM. They were mostly obese 63(50.8\%)and had excessive GWG 48 (38.7\%), but $54(43.5 \%)$ had gained weight according to IOM' recommendations also developed GDM.

Sathyapalan et al. [22]. 2007 reported higher incidence of GDM in obese population, comparatively, Chu SY et al. found $11.5 \%$ of GDM in women with moderate to severe obesity [23].

The overall Miscarriage rate was $10(2.7 \%)$.This was high in overweight women who had excessive GWG i.e. 7(70\%), similarly an Irish study $[24,25]$ of 1200 women showed the rate of miscarriage $2.8 \%$.

It was noted that the rate of instrumental deliveries and caesarean sections were higher in obese women 13(54.2\%) and $97(45.3 \%)$ respectively. A study from Dublin [26], reported $45.3 \% \mathrm{CS}$ rate, Margaretha H. et al. [27] and Chu et al. [28] quoted the similar findings.

We found the incidence of pre-term labor $18.9 \%$, LBW 23.5\%, low Apgar scores 30.3\% and Nicu admissions 47\%. These were more commonly seen in overweight and obese women even with recommended weight gain. Farah et al. [29] reported the similar findings. Barbara Abrams [30] recently concluded from a critical review of the relation between GWG and preterm labor that the rate of GWG below the lower limit of IOM's recommended ranges, especially in late pregnancy related to a higher risk of preterm birth. It showed that IOM recommendations are still excessive for our population. We need local guidelines for GWG to reduce these rates.

Similarly, abruption and anesthesia complications (spinal headache) were found to be higher in overweight and obese women who had GWG within the recommended IOM's ranges.

Data from china $[16,17]$ had indicated that the prevalence of hypertension, diabetes and clustering of risk factors all increased with growing BMI'S even at indices below the WHO's recommended BMI classification for overweight. This data and our study explained clearly that Asians particularly Pakistani women needs local recommendations for BMI and GWG to reduce the untoward effects on their pregnancy.

\section{CONCLUSION}

Pre-pregnancy BMI and excessive GWG significantly affect pregnancy outcomes. So, any intervention targeted to prevent 
excessive GWG should therefore be started before pregnancy.

Asian women has significantly high risk of pregnancy related complications even at upper limit of normal BMI and GWG ranges, because of their genetic predisposition and life style factors, so there is a need to further refine BMI and GWG recommendations for these women. Health care workers should also be trained for counseling about pre-pregnancy $\mathrm{BMI}$ and weight gain during pregnancy.

\section{LIST OF ABBREVIATIONS}

ACOG (American College of Obstetricians and

Gynecologists)

BMI (Body Mass Index)

GDM (Gestational Diabetes Mellitus)

GWG (Gestational Weight Gain)

IOM (Institute of Medicine)

LBW (Low Birth Weight)

LGA (Large for Gestational Age)

NICU (Neonatal Intensive Care Unit Admission)

PIH (Pregnancy Induced Hypertension)

WHO (World Health Organization)

\section{CONFLICT OF INTEREST}

Declared none.

\section{ACKNOWLEDGEMENTS}

Declared none.

\section{REFERENCES}

[1] Oken E, Kleinman KP, Belfort MB, et al. Associations of gestational weight gain with short- and longer-term maternal and child health outcomes. Am J Epidemiol 2009; 170: 173-80. DOI: 10.1093/aje/kwp101

[2] Khashan AS, Kenny LC. The effects of maternal body mass index on pregnancy outcome. Eur J Epidemiol 2009; 24: 697-705. DOI: $10.1007 / \mathrm{s} 10654-009-9375-2$

[3] Streuling I, Beyerlein A, von Kries R. Can gestational weight gain be modified by increasing physical activity and diet counseling? A meta-analysis of interventional trials. Am J Clin Nutr 2010; 92: 678-87. DOI: 10.3945/ajcn.2010.29363

[4] Tanentsapf I, Heitmann BL, Adegboye AR. Systematic review of clinical trials on dietary interventions to prevent excessive weight gain during pregnancy among normal weight, overweight and obese women. BMC Preg Childbirth 2011; 11: 81. DOI: $10.1186 / 1471-2393-11-81$

[5] Kowal C, Kuk J, Tamim H. Characteristics of weight gain in pregnancy among Canadian women. Matern Child Health J 2012; 6: 668-76. DOI: 10.1007/s10995-011-0771-3
[6] Heude B, Thiébaugeorges $\mathrm{O}$, Goua V, et al. Pre-pregnancy body mass index and weight gain during pregnancy: Relations with gestational diabetes and hypertension, and birth outcomes. Matern Child Health J 2012; 16: 355-63.

DOI: $10.1007 / \mathrm{s} 10995-011-0741-9$

[7] WHO Global Database on Body Mass Index. 2018; Available at: http://apps.who.int/bmi/index.jsp.

[8] Siega-Riz AM, Viswanathan M, Moos MK, et al. A systematic review of outcomes of maternal weight gain according to the institute of medicine recommendations: Birthweight, fetal growth, and postpartum weight retention. Am J Obstet Gynecol 2009; 201: 339.e1-14.

DOI: 10.1016/j.ajog.2009.07.002

[9] Munim, S, Maheen, H. Association of gestational weight gain and pre-pregnancy body mass index with adverse pregnancy outcome. J Coll Physicians Surg Pak 2012; 22(11): 694-8.

[10] O'Higgins A, Turner MJ. The obese women in late pregnancy and labour. Chapter 5. In: Ledger W, Clark J, Eds. Recent Advances in Obstetrics and Gynaecology 26. USA: JP Medical Publishers 2015; p. 48.

[11] Sunsaneevithayakul $\mathrm{P}$, Titapant $\mathrm{V}$, Ruangvutilert $\mathrm{P}$, et al. Relation between gestational weight gain and pregnancy outcomes. J Obs Gynaecol Res 2014; 40: 995-1001. DOI: $10.1111 /$ jog. 12293

[12] Sebastián MG, Angel SH, Irene VZ, et al. Abnormal maternal body mass index and obstetric and neonatal outcome. J Matern Fetal Neonatal Med 2012, 25: 308-12.

DOI: $10.3109 / 14767058.2011 .575905$

[13] American College of Obstetricians and Gynecologists. ACOG Committee opinion no. 549: Obesity in pregnancy. Obstet Gynecol 2013; 121: 213-7.

DOI: 10.1097/01.AOG.0000425667.10377.60

[14] Baron CM1, Girling LG, Mathieson AL, et al. Obesity and neonatal outcomes in obese parturient. J Matern Fetal Neonatal Med 2010; 23: 906-13. DOI: 10.3109/14767050903338472

[15] Lynch CM, Sexton DJ, Hession M, et al. Obesity and mode of delivery in primigravid and multigravid women. Am J Perinatol 2008; 25: 163-7. DOI: $10.1055 / \mathrm{s}-2008-1061496$

[16] Chen Z, Du J, Shao L, et al. Prepregnancy body mass index, gestational weight gain,and pregnancy outcomes in China. Int J Gynecol Obstet 2010; 109(1): 41-4.

DOI: 10.1016/j.ijgo.2009.10.015

[17] Shi P, Yang W, Yu Q, et al. Overweight, gestational weight gain and elevated glucose and their association with Macrosomia in Chinese Pregnant women. Matern Child Health J 2014; 18: 10-5. DOI: 10.1007/s10995-013-1253-6 
[18] O"Brien TE, Ray JG, Chan WS. Maternal body mass index and the risk of preeclampsia: A systematic overview. Epedemiology 2003; 14: 368-74.

DOI: $10.1097 / 00001648-200305000-00020$

[19] Cnossen JS, Leeflang MMG, de Haan EEM, et al. Accuracy of body mass index in predicting pre-eclampsia: Bivariate meta-analysis. BJOG 2007; 114: 1477-85.

DOI: $10.1111 / j .1471-0528.2007 .01483 . x$

[20] Hellerstedt WL, Himes JH, Story M, et al. The effects of cigarette smoking and gestational weight change on birth outcomes in obese and normal-weight women. Am J Public Health 1997; 87(4): 591-6. DOI: 10.2105/AJPH.87.4.591

[21] Sathyapalan T, Mellor D, Atkin SL. Obesity and gestational diabetes. Semin Fetal Neonate Med 2010; 15: 89-93.

DOI: 10.1016/j.siny.2009.09.002

[22] Chu SY, Callaghan WM, Kim SY, et al. Maternal obesity and risk of gestational diabetes mellitus. Diabetes Care 2007; 30(8): 2070-6. DOI: 10.2337/dc06-2559a

[23] Turner MJ, Farah N. Gestational weight gain and birth weight. Ir Med J 2010; 103: 293-4.

[24] Turner MJ, Fattah C, O"Connor N, et al. Body Mass Index and spontaneous miscarriage. Eur J Obstet Gynecol Reprod Biol 2010; 151: 168-70. DOI: 10.1016/j.ejogrb.2010.04.021
[25] Farah N, Maher N, Barry S, et al. Maternal morbid obesity and obstetric outcomes. Obes Facts 2009; 2: 352-4.

DOI: $10.1159 / 000261951$

[26] Margaretha H, Anne LB, Anna W, et al. Associations of pre-pregnancy body mass index and gestational weight gain with pregnancy outcome and post-partum weight retention: A prospective observational cohort study. BMC Pregnancy Childbirth 2014; 14: 201. DOI: 10.1186/1471-2393-14-201

[27] Chu SY, Kim SY, Schmid CH, et al. Maternal obesity and risk of cesarean delivery: A meta-analysis. Obes Rev 2007; 8: 385-94. DOI: 10.1111/j.1467-789X.2007.00397.x

[28] Farah N, Stuart B, Donnelly V, et al. The influence of maternal body composition on birth weight. Eur J Obstet Gynecol Reprod Biol 2011; 157: 14-7.

DOI: 10.1016/j.ejogrb.2010.12.047

[29] Abrams B, Newman V. Small-for-gestational-age birth: Maternal predictors and comparison with risk factors of spontaneous preterm delivery in the same cohort. Am J Obstet Gynecol 1991; 164(3): 785-90. DOI: $10.1016 / 0002-9378(91) 90516-\mathrm{T}$

[30] Ali HS, Lakhani N. Effect of obesity and its outcome among pregnant women. Pak J Med Sci 2011; 27(5): 1126-8. 